\title{
Effect of Gonadotropins during Hot Summer Season Given at Different Times after Weaning on Selected Reproductive Indicators of the Sow
}

\author{
S.P. FRANEK, G. BILKEI \\ Bilkei Consulting, Dübendorf, Switzerland \\ Received July 11, 2007 \\ Accepted March 13, 2008
}

\begin{abstract}
Franek S.P., G. Bilkei: Effect of Gonadotropins during Hot Summer Season Given at Different Times after Weaning on Selected Reproductive Indicators of the Sow. Acta Vet. Brno 2008, 77: 193-198.

The experiment was performed on a large indoor herd during a hot season period in Alföld, Hungary. The post-weaning sows (F1 and F2 of Large White $\times$ Landrace mated to Duroc boars (mean parity 3.4 +/-0.7 SD; mean body condition 3.01 +/-0.3 SD, previous lactation length of $28.3+/-1.5 \mathrm{~d}$ ) were divided into four groups of similar body condition, lactation length and parity and were treated as follows:

Group 1: sows $(n=420)$ were injected subcutaneously with 400 I.U. of Gonadotropinum sericum (pregnant mare serum gonadotropin, PMSG [eCG]) and 200 I.U. of Gonadotropinum chorionicum (human choriongonadotropin, HCG [hCG]) one day after weaning.

Group 2: sows $(\mathrm{n}=405)$ received subcutaneously $4 \mathrm{ml}$ of saline injection one day after weaning.

Group 3: sows $(n=425)$, purposely chosen from among animals that did not show heat within 7 days after weaning, were treated on day 7 post-weaning with PMSG and HCG as the animals in group 1.

Group 4: sows $(n=415)$ purposely chosen from among animals that did not show heat within 7 days after weaning, were treated on day 7 post-weaning as group 2.

Sows expressing oestrus, sows ovulating after treatment, treatment to oestrus intervals and follicular sizes were evaluated. The number of sows expressing oestrus, sows ovulating, and treatment to oestrus intervals differed between the groups (group 1 vs. 2 : $P<0.05$, group 3 vs. 4 : $P<0.01$ ). The sows treated with PMSG and HCG on day 7 post-weaning (group 3 ) had smaller $(P<0.05)$ follicular diameters compared to the sows that were treated one day after weaning. Group 4 sows had a smaller follicular diameter $(3.6+/-0.6 \mathrm{~mm})$ compared to group $1(P<0.001)$ and $3(P<0.01)$.

The present results show that the gonadotropin treatment one day after weaning or in the case of anoestrus 7 days after weaning overrides the negative effects of the hot summer season and effectively prevents seasonal infertility of the breeding sow.
\end{abstract}

Swine, reproduction, seasonal anoestrus, gonadotropin, season, infertility

High ambient temperatures may negatively influence the reproductive performance of the sow (Britt et al. 1983). In a large Hungarian study, seasonal infertility was manifested by - post-weaning anoestrus,

- prolonged weaning to oestrus intervals,

- increased embryonic mortality,

- increased abortions and stillbirths,

- reduced farrowing rates, and

- decreased born and weaned litter sizes (Bilkei 1995).

The effects of hot season on weaning-to-oestrus intervals are mediated by ovarian follicular development (Soede et al. 1998). Sows with small follicles $(<4 \mathrm{~mm})$ on day 3 after weaning are more likely to experience anoestrus or delayed oestrus compared to sows with larger follicles (Bracken et al. 2003). High ambient temperature during lactation was associated with suppressed follicular growth during lactation (Lucy et al. 2001). 
Some studies have demonstrated that elevated temperatures significantly decrease the ovulation rate (Bilkei 1995; Tegue et al. 1968), whereas other studies revealed no such effect (Edwards et al. 1968; Tomkins et al. 1967). Tomkins et al. (1967) and Bilkei (1995) observed increased embryonic mortality when sows were exposed to high ambient temperature within 3 weeks post-mating, but found no effect of high temperature on the litter during middle and late pregnancy.

Conception losses are the highest when females are heat-stressed around the time of conception and implantation and are manifested in regular returns to oestrus if all the litter is dead, or to smaller litter sizes if embryonic mortality is limited (Edwards et al. 1968). Elevated ambient temperature decreases the motility and quantity of sperm and increases in the proportion of abnormal sperm cells of the boar (Wrathall 1982).

More sows of parity 1 - 2 have a seasonal delay in the post-weaning return to oestrus than sows of parity 3 - 5 (Bilkei 1995). The return to oestrus is influenced not only by season but by other production factors, such as the genetics, feeding, management (Edwards et al. 1968; Koketsu and Dial 1997; Kornegay and Thomas 1983), post-parturient and post-weaning bio- and zootechnique (Bilkei 1995), outdoor production (Hoffmann and Bilkei 2003; Thaker and Bilkei 2005) and body condition (Hoffmann and Bilkei 2003; Prunier and Quesnel 2000).

Seasonal infertility in domestic pigs has been recognized in a number of countries including Australia (Love 1981), USA (Britt et al. 1983; Hurtgen and Leman 1980), UK (Peters and Pitt 2003; Kornegay and Thomas 1983), Kenya (Boma and Bilkei 2006), Eastern Europe (Almond and Bilkei 2005), and Hungary (Bilkei 1995). The severity varied between countries, but in general, the hotter countries experienced more severe effects.

During hot summer periods, 400 I.U. of pregnant mare serum gonadotropin, PMSG [eCG]) and 200 I.U. of human choriongonadotropin, HCG [hCG]) support post-weaning oestrus and ovulation (Britt et al. 1983; Hurtgen and Leman 1980). According to Bracken et al. (2006) delaying gonadotropin injection until day 7 after weaning may provide an economic advantage. In the study PMSG and HCG injection on day 7 after weaning to seasonally anoestrous sows enhanced ovarian follicular development, and resulted in a higher oestrus rate compared with untreated control sows (Bracken et al. 2006).

Due to different evaluation periods, feeding, climatic and genetic differences, it is notoriously difficult to compare published reproductive data on season-related differences (Wrathall 1982). Therefore, the correct judgement of seasonal infertility of the sow can be only made if parity, body condition, feeding, production system, reproductive management and the time window of an evaluation period are similar (Bilkei 1995). The aim of the present Hungarian study was to evaluate the effects of a single injection of PMSG and HCG given one day or on day 7 post-weaning.

\section{Materials and Methods}

The experiment was performed on a large indoor herd of 5,900 sows in Alföld, Hungary during hot summer season periods where the mean daily temperature between $10.00-17.00 \mathrm{~h}$ were $35.1+/-2.2^{\circ} \mathrm{C}$ for at least 3 consecutive days. The sows were of similar genetics (F1 and F2 of Large White $\times$ Landrace mated to Duroc boars, mean parity $3.4+/-0.7 \mathrm{SD}$; mean body condition $3.01+/-0.3 \mathrm{SD})$.

Pre-experimental investigation showed an annual replacement rate of $31+/-1-9 \%$. The herd was subclinically infected with Actinobacillus pleuropneumoniae, toxin-producing Pasteurella multocida and Mycoplasma hyopneumoniae. In this herd enterotoxigenic Escherichia (E.) coli (ETEC, pilus types: F4, F5, F41, 987P, F18) and verotoxigenic E. coli (VETEC pilus F18) were present.

Standard farm management included: weaning at 4 wk of lactation, group rotation of 30 females in the "all-in all-out system", double artificial insemination (AI), and routine culling after parity 8 . The sows were vaccinated against parvovirosis, erysipelas, leptospirosis, Clostridium perfringens $C$, and $E$. coli.

The sows were kept in high investment facilities (farrowing crates, individual gestation crates, eros centre). 
The sows were AI at their $1^{\text {st }}$ post-weaning oestrus. After a positive pregnancy diagnosis, the sows were moved into gestation barns, where they spent the whole gestation period. On the $110^{\text {th }}$ day of pregnancy the sows were transferred into farrowing barns, where they spent their whole lactation of $4 \mathrm{wk}$.

The sows were fed as follows:

From AI to day 89 of gestation, $2 \mathrm{~kg} / \mathrm{sow} / \mathrm{d}$, and from day 90 to 110 of gestation $3 \mathrm{~kg} / \mathrm{sow} / \mathrm{d}$ of a commercial gestation ration containing 12.2 megajoul digestible energy (MJ DE) $/ \mathrm{kg}, 125 \mathrm{~g} / \mathrm{kg}$ crude protein, $6.5 \mathrm{~g} / \mathrm{kg}$ lysine, $8 \mathrm{~g} / \mathrm{kg}$ calcium, and $6 \mathrm{~g} / \mathrm{kg}$ phosphorus.

From d 110 of gestation to parturition, $3 \mathrm{~kg} / \mathrm{sow} / \mathrm{d}$ of lactating diet. On the day of parturition, $1 \mathrm{~kg}$ of feed was given. Beginning with the $2^{\text {nd }}$ day after parturition, sows were fed ad libitum with the same lactation diet, containing 13.0 MJ DE/kg, $180 \mathrm{~g} / \mathrm{kg}$ crude protein, $10 \mathrm{~g} / \mathrm{kg}$ lysine, $8 \mathrm{~g} / \mathrm{kg}$ calcium, and $6 \mathrm{~g} / \mathrm{kg}$ phosphorus.

From weaning to AI the sows received the same lactation diet ad libitum, supplemented with 300 IU vitamin E per $\mathrm{kg}$ and $500 \mathrm{~g}$ potato starch/sow/d ("flushing").

The sows received water supply ad libitum with a high water flow rate $(1.5-2 \mathrm{l} / \mathrm{min})$.

The weaned sows were divided during the trial period into four groups of similar parity, previous lactation length $(28.3+/-1.5 \mathrm{~d})$, and body condition according to computer-generated list, and were treated as follows:

Group 1 (the sows were marked with a red water resistant colour): $\mathrm{n}=420$ sows, mean parity $2.92+/-0.31$, mean body condition $3.0+/-0.24$, weaning on day $28.1+/-0.8$ of lactation). The sows were injected subcutaneously with 400 I.U. of PMSG and 200 I.U. of HCG (Suidan ${ }^{\circledR}$, Alvetra and Werfft AG, Vienna, Austria) one day after weaning. Oestrus detection began on day 3 post-weaning.

Group 2 (the sows were marked with a blue water resistant colour): $n=405$ sows, mean parity $2.99+/-0.39$, mean body condition $3.1+/-0.29$, weaning on day $27.9+/-0.9$ of lactation). The sows received $4 \mathrm{ml}$ of saline injection one day after weaning. Oestrus detection began on day 3 post-weaning.

Group 3 (the sows were marked with a black water resistant colour): $\mathrm{n}=425$ sows, mean parity $2.89+/-0.33$, mean body condition $3.3+/-0.21$, weaning on day $27.8+/-0.7$ of lactation. These sows had no detectable oestrus signs until day 7 post-weaning. The sows were treated as the animals in group 1 . Oestrus detection began on day 3 post-weaning and was continuously done until AI.

Group 4 (the sows were marked with a green water resistant colour): $\mathrm{n}=415$ sows with no detectable oestrus signs. Mean parity was $2.77+/-0.41$, mean body condition $3.0+/-0.31$, weaning on day $28.2+/-0.6$ of lactation. The sows were not treated at weaning. On day 7 post-weaning the sows were treated as group 2. Oestrus detection began on day 3 post-weaning and was continuously done until AI.

Sows coming to oestrus, sows ovulating after the treatment, treatment to oestrus intervals and follicular sizes were evaluated.

All sows were subjected twice daily (early morning and late afternoon) to routine rectal ultrasonography from day 3 after weaning until AI, as follows: An Aloka $500 \mathrm{~V}$ ultrasound machine (Corometrics Medical Systems Inc, Wallingford, Connecticut) and a 7.5 MHz linear transducer were used for measuring ovarian follicles. Ovarian follicles $>2 \mathrm{~mm}$ in diameter were measured. The mean follicular diameter was calculated for the measured follicles. The day of ovulation was defined as the day of disappearance of pre-ovulatory follicles $(>6 \mathrm{~mm}$ diameter).

The body condition on the day of weaning was scored according to Bilkei (1995). Sow weight loss and "back fat loss" during lactation were not recorded. A trained farm technician performed oestrus detection by using the back-pressure test with fence-line boar contact. Sows were considered to be in oestrus when they exhibited a "standing reflex" in the presence of a boar.

Statistical analysis

Intervals from treatment to the onset of oestrus and from treatment to ovulation were calculated from breeding and ultrasonography records. Data were analyzed using the general linear models procedure (PROC GLM) of the Statistical Analysis System (19). The PROC GLM procedure used the method of least squares to fit general linear models. The mean follicular diameter was tested for the effects of treatment, farrowing group, treatment by farrowing group, sow nested within treatment by farrowing group (error term for the preceding effects), day, and treatment by day. The categorical model procedure of SAS (PROC CATMOD) was used to test categorical data. The PROC CATMOD procedure fits linear models to functions of response frequencies. The effect of treatment on the rates of oestrus expression, AI, ovulation, and pregnancy was tested. The rate was defined as the number experiencing the event divided by the total number of treated sows. Type 1 error levels $(P$ values $)$ of $<0.05$ were considered significant.

\section{Results}

The number of sows expressing oestrus differed between the groups: group one: $94 \%$, group two: $75 \%$ (group 1 and 2: $P<0.05$ ), group three: $36 \%$, group four: $13 \%$ (group 3 and 4: $P<0.01)$ (Table 1).

In the present study follicles larger than $6 \mathrm{~mm}$ were judged as a sign of ovulation. The number of sows ovulating showed significant differences between the groups: group 1 vs. 
group 2: $P<0.05$, group 3 vs. group 4: $P<0.01$; group 1 and group 2 vs. group 3 and 4: $P$ $<0.001)$ (Table 1).

The treatment to oestrus interval differed between the groups: group one 3. 8+/-0.4 d, group two $5.1+/-0.4 \mathrm{~d}$ (group 1 and $2: P<0.05$ ), group three, $4.5+/-0.6 \mathrm{~d}$, group four 12.5 $+/-2.6 \mathrm{~d}$ (group 3 and 4: $P<0.001$; group 1, 2 and 3 vs. group 4: $P<0.001$ ) (Table 1).

The follicular diameter was larger in group 1 sows treated with PMSG and HCG at weaning $(5.4+/-0.4 \mathrm{~mm})$ compared with group 2 sows treated with saline at weaning $(3.8$ $+/-0.3 \mathrm{~mm})(P<0.001)$. The sows of group 3 (treated with PMSG and HCG on day 7 postweaning) had a smaller follicular diameter $(4.7+/-0.5 \mathrm{~mm})(P<0.05)$ compared with the sows of group 1 (treated with PMSG and HCG on the day of weaning). Group 4 sows had a smaller follicular diameter $(3.6+/-0.6 \mathrm{~mm})$ compared with group $1(P<0.001)$ and $3(P$ $<0.01$ ) (Table 1).

Table 1. The effect of gonadotropin treatment routinely given one day post weaning, or given on day 7 post weaning to such sows that did not express oestrus within 7 days after weaning on expressing oestrus rate, ovulation rate, treatment to oestrus intervals and follicular size

\begin{tabular}{|l|c|c|c|c|}
\hline \multicolumn{5}{|c|}{ Indicator } \\
\hline & Group 1 & Group 2 & Group 3 & Group 4 \\
\hline Oestrus rate $\mathrm{n} / \mathrm{nn}=\%$ & $394 / 420=94.05 \mathrm{a}$ & $304 / 405=75.1 \mathrm{~b}$ & $153 / 425=36 \mathrm{~A}$ & $54 / 415=13.0 \mathrm{~B}$ \\
\hline Ovulation rate $\mathrm{n} / \mathrm{nn}=\%$ & $390 / 420=92.86 \mathrm{a}$ & $287 / 405=71.39 \mathrm{~b}$ & $103 / 425=24.26 \mathrm{~A}$ & $54 / 415=5.5 .4 \mathrm{~B}$ \\
\hline Treatment to oestrus intervals d $\pm \mathrm{SEM}$ & $3.8 \pm 0.4 \mathrm{a} A$ & $5.1 \pm 0.4 \mathrm{~b} A$ & $4.5 \pm 0.6 \mathrm{~A} A$ & $12.5 \pm 2.6 \mathrm{~B} B$ \\
\hline Follicular size $\mathrm{mm} \pm \mathrm{SEM}$ & $5.4 \pm 0.4 \mathrm{a} A$ & $3.8 \pm 0.3 \mathrm{~B}$ & $4.7 \pm 0.5 \mathrm{~b} A$ & $3.6 \pm 0.6 \mathrm{~B}$ \\
\hline
\end{tabular}

$\mathrm{n}$ : number of animals in a group

$\mathrm{nn}$ : number of positively tested animals in a group

a, b: $P<0.05$

A, B: $P<0.01$

A, $B: P<0.001$

Legend

Group 1: sows $(n=420)$ were injected subcutaneously with 400 I.U. of Gonadotropinum sericum (pregnant mare serum gonadotropin, PMSG [eCG]) and 200 I.U. of Gonadotropinum chorionicum (human choriongonadotropin, HCG [hCG]) one day after weaning.

Group 2: sows $(\mathrm{n}=405)$ received subcutaneously $4 \mathrm{ml}$ of saline injection one day after weaning.

Group 3: sows $(n=425)$, purposely chosen from animals that did not show heat within 7 days after weaning, were treated on day 7 postweaning with PMSG and HCG as the animals in group 1.

Group 4: sows $(n=415)$ purposely chosen from animals that did not show heat within 7 days after weaning, were treated on day 7 postweaning as group 2 .

\section{Discussion}

In this study, the benefits of PMSG and HCG treatment were demonstrated both in sows routinely treated with PMSG and HCG one day following weaning, and in sows diagnosed for anoestrus and treated with PMSG and HCG on day 7 post-weaning. PMSG and HCG-treated sows had significantly larger follicles than the control sows. The present practical findings show that gonadotropin treatment one day after weaning or in the case of anoestrus 7 days after weaning overrides the negative effects of a hot summer season and effectively prevents seasonal infertility of the breeding sow. Measurement of the follicular size shows that despite the hot summer season, gonadotropin treatment effectively stimulates follicular growth. This indicates that sows, whose productivity would be compromised by seasonal infertility, might be effectively treated with PMSG and HCG not only at weaning but 7 days after weaning, as well. However, this delayed treatment results in lesser follicular growth compared with the animals having received PMSG and HCG treatment one day after weaning. Infertility in sows occurs in the summer when temperature and humidity are high and the photoperiod is long (Bilkei 1995; Boma and Bilkei 2006; Bracken etal.2003, 2006; Koketsu and Dial 1997; Kornegay and Thomas 
1983; Love 1981; Prunier and Quesnel 2000; Thaker and Bilkei 2005; Xue et al. 1994). Some effects of the heat stress on reproduction may be mediated by a reduced feed intake in hyperthermic sows during the hot season (Koketsu and Dial 1997). The high daytime outside ambient temperature during the present study approached $36^{\circ} \mathrm{C}$, a temperature that has already been associated with seasonal infertility and anoestrus (Bilkei 1995). According to Lucy et al. (2001) seasonal infertility is associated with small and non-growing follicles. Consistent with Lucy et al. (2001), the present results show an association between small and non-growing follicles and anoestrus. The gonadotropin treatment apparently restored oestrus and ovulation in sows that would have remained anoestrous without a gonadotropin treatment.

The European wild pig (Sus scrofa) has strong seasonal reproductive patterns. It has its mating activity peaks in late autumn-early winter with the birth of a litter in spring, and although the litters are weaned in summer, mating ceases between June and September. It appears likely that the modern domestic pig has retained this sensitivity to season (Bilkei 1995).

The mechanism to control seasonal breeding patterns is well described for the sheep. Seasonality in sheep is determined by the changing photoperiod, with a decreasing day length in the early autumn being the reason for the onset of breeding activity. The effects of the changing photoperiod on gonadotropin secretion are mediated by changes in melatonin secretion from the pineal gland. While there is evidence that changes in gonadotropin production in the pigs are similar to this model (Britt et al. 1983), there are no reliable data on melatonin production in pigs. Both photoperiod and ambient temperature change with season and influence the weaning-to-service intervals through direct effects on the hypothalmo-hypophyseal-ovarian axis (Britt et al. 1983).

A critical remark: it is possible to evaluate the finding of preovulatory follicles but this finding must not be interchanged with the term of ovulation level. Ovulation is influenced by a number of factors, especially - as in the present experiment - during the hot summer season. Ovulation level could have been confirmed besides ultrasonography by an increase of progesterone level. Due to technical reasons this has not been performed in the present experiment.

The authors of the present study conclude that PMSG and HCG treatment at weaning or on day 7 after weaning is a successful method to overcome summer infertility problems. Delaying the PMSG and HCG treatment until day 7 after weaning might have the advantage that only anoestrous sows are treated.

\section{Vliv gonadotropinů podávaných $\mathrm{v}$ různých časových intervalech po odstavu na některé ukazatele reprodukční užitkovosti prasnic během horkého léta}

Studie byla provedena během horkého letního období v Alföldu (Mad’arsko) ve velkém stájovém chovu. Prasnice F1 a F2 plemene velkého bílého a Landrace krrížené s kanci plemene Duroc (průměrný počet selat 3,4 $\pm 0,7 \mathrm{SD}$, tělesná kondice $3,01 \pm 0,3 \mathrm{SD}$, délka předchozí laktace $28,3 \pm 1,5$ dne) byly po odstavu rozděleny do 4 skupin podle kondice, délky laktace a počtu selat. Prasnicím skupiny $1(\mathrm{n}=420)$ bylo subkutánně podáno 400 U.I. Gonadotropinum sericum (sérový gonadotropin březích klisen, pregnant mare serum gonadotropin, PMSG [eCG]) a 200 U.I. Gonadotropinum chorionicum (lidský choriový gonadotropin, human choriongonadotropin, HCG [hCG]) jeden den po odstavu. Prasnicím skupiny $2(\mathrm{n}=405)$ byly subkutánně podány $4 \mathrm{ml}$ fyziologického roztoku jeden den po odstavu. Prasnice skupiny $3(n=425)$, které byly účelově vybrány, protože u nich 7 dní po odstavu nebyly pozorovány projevy estru, byly 7 . den po odstavu ošetřeny PMSG a HCG stejně jako prasnice skupiny 1 . Prasnice skupiny $4(n=415)$, které byly rovněž účelově vybrány, protože u nich 7 dní po odstavu nebyly pozorovány projevy estru, byly 7 . den po odstavu ošetřeny stejně jako prasnice skupiny 2 . Bylo vyhodnocováno, u kolika prasnic 
se projevily znaky estru, kolik jich ovulovalo, jaký byl interval mezi ošetřením a estrem, a jaká byla velikost folikulů. Mezi skupinami (skupina 1 vs. 2: $P<0,05$, skupina 3 vs.4: $P<0,01)$ byly rozdíly v počtu prasnic s projevy estru, s ovulací, a co do intervalu mezi ošetřením a estrem. Prasnice ošetřené PMSG a HCG 7. den po odstavu (skupina 3) měly menší folikuly $(\mathrm{P}<0.05)$ ve srovnání s prasnicemi, které byly ošetřeny 1 den po odstavu. Prasnice skupiny 4 měly menší folikuly $(3,6 \pm 0,6 \mathrm{~mm})$ ve srovnání se skupinou 1 $(P<0,001)$ a $3(P<0,01)$. Výsledky ukazují, že ošetření gonadotropinem 1 den po odstavu nebo v př́padě anestru 7. den po odstavu potlačuje negativní vliv horkého letního období a účinně předchází sezónní neplodnosti chovných prasnic.

\section{References}

ALMOND P, BILKEI G 2005: Seasonal infertility in large pig production units in an Eastern-European climate. Austral Vet J 83: 344-346

BILKEI G 1995: Herd health strategy for improving the reproductive performance of pigs. Proceedings Eighth "In-between" Symposium of the International Society for Animal Hygiene. Hung Vet J 10: 766-768

BOMA MH, BILKEI G 2006: Seasonal infertility in Kenyan pig breeding units. Onderstepoort J Vet Res 73: 229-232

BRACKEN CJ, LAMBERSON WR, SAFRANSKI TJ, LUCY MC 2003: Factors affecting follicular populations on day 3 post-weaning and interval to ovulation in a commercial sow herd. Theriogenology 60: 11-20

BRACKEN CJ, SEAMAN-BRIDGES JS, SAFRANSKI TJ, LUCY MC 2006: Ovarian follicular development, estrus, and ovulation in seasonally anestrous sows treated seven days post weaning with equine and human chorinonic gonadotropins. J Swine Health Prod 14: 207-209

BRITT JH, SZAREK VE, LEVIS DG 1983: Characterization of summer infertility of sows in large confinement units. Theriogenology 20: 133-140

EDWARDS RL, OMTVEDT IT, TURMAN EJ, STEPHENS DF, MAHONEY GWA 1968: Reproductive performance of gilts following heat stress prior to breeding and in early gestation. J Anim Sci 27: 1634-1637

HOFFMANN CK, BILKEI G 2003: Effect of body condition of postweaning "flushed" sows and weaning-tomating interval on sow reproductive performance. Vet Rec 152: 261-263

HURTGEN JP, LEMAN AD 1980: Seasonal influence on the fertility of sows and gilts. J Am Vet Med Assoc 177: $631-635$

KOKETSU Y, DIAL GD 1997: Factors influencing the post weaning reproductive performance of sows on commercial farms. Theriogenology 47: 1445-1461

KORNEGAY ET, THOMAS HR 1983: Effects of air-conditioned versus naturally ventilated housing during hot weather on the reproductive efficiency of gilts and sows. Livest Prod Sci 10: 387-395

LOVE RJ 1981: Seasonal infertility in pigs. Vet Rec 109: 407-409

LUCY MC, LIU J, BOYD CK, BRACKEN CJ 2001: Ovarian follicular growth in sows. J Reprod Fertil Suppl 58: $31-45$

PETERS AR, PITT RL 2003: Seasonal infertility in pigs in the east of England. Pig J 52: 13-27

PRUNIER A, QUESNEL H 2000: Influence of the nutritional status on ovarian development in female pigs. Anim Reprod Sci 60-61: 185-197

SAS/STAT® User's Guide 1988. Version 6. Cary, North Carolina, SAS Institute Inc.

SOEDE NM, HAZELEGER W, KEMP B 1998: Follicle size and the process of ovulation in sows as studied with ultrasound. Reprod Domest Anim 33: 239-244

TEGUE HS, ROLLER WR, GRIFO AP 1968: Influence of high temperature and humidity on the reproductive performance of swine. J Anim Sci 27: 408-411

THAKER MYC, BILKEI G 2005: Lactation weight loss influences subsequent reproductive performance of sows. Anim Reprod Sci 88: 309-318

TOMKINS EC, HEIDENREICH CJ, STOB M 1967: Effect of post-breeding thermal stress on embryonic mortality in swine. J Anim Sci 26: 377-380

WRATHALL AE 1982: Reproductive problems in outdoor pigs. Proc Int Pig Vet Soc Mexico: 205

XUE JL, DIAL GD, MARSH WE, DAVIES PR 1994: Multiple manifestations of season on reproductive performance of commercial swine. J Am Vet Med Assoc 204: 1486-1489 